\title{
The Diversity of DeBt Crises IN EUROPE
}

\author{
Jerome L. Stein
}

The foreign debts of the European countries are at the core of the current crises. Generally, the crises are attributed to government budget deficits in excess of the values stated in the Stability and Growth Pact (SGP), as part of the Maastricht treaty. Proposals for reform generally involve increasing the powers of the European Union to monitor fiscal policies of the national governments and increasing bank regulation.

This article seeks to explain intercountry differences in the debt crises in Europe. Is there a single explanation, cause? Specifically, were the crises due to government budget deficits or to the private sector? The answer will determine the appropriate policies to prevent a recurrence. The Stability and Growth Pact, Maastricht Treaty, and the European Union focused on rules concerning government debt ratios and deficit ratios. But they ignored the problem of "excessive" debt ratios in the private sector that led to a crisis in the financial markets.

Neither the markets nor the central banks anticipated the crises until it was too late. My basic questions are: What is an "excessive" private sector debt ratio that is likely to lead to a crisis? What are the theoretically based — as opposed to ad hoc — early warning signals of debt crises? The answers determine to a large extent how one should evaluate proposals for economic reform to avert future crises.

Cato Journal, Vol. 31, No. 2 (Spring/Summer 2011). Copyright (C) Cato Institute. All rights reserved.

Jerome L. Stein is the Eastman Professor of Political Economy (Emeritus) at Brown University and Visiting Professor in the Research Division for Applied Mathematics. He thanks Peter Clark and William Niskanen for their excellent suggestions. 


\section{Cato Journal}

\section{Basic Statistics Related to the Origins of the Crises}

Table 1 presents the government structural balance as a percentage of potential GDP for the eurozone and selected countries. It refers to the general government cyclically adjusted balance adjusted for nonstructural elements beyond the economic cycle. Structural balances as a percentage of potential GDP in Greece and Portugal are different from Ireland and Spain. The last row contains the mean and standard deviation in the pre-crisis period 1998-2007. In Greece and Portugal the structural balances have been on average twice as high as in the eurozone, whereas in Spain they have been significantly lower, and in Ireland they have been similar to the eurozone.

Table 2 presents government net debt as a percentage of GDP for Spain, Ireland, Portugal, and Greece. When the crisis in the private banking sector occurred in some countries particularly Ireland and Spain, the government bailed out the banks by purchasing private debt in exchange for public debt. The government (taxpayers) then became the debtor to foreign investors. The effect of the

TABLE 1

Government Structural Balance as a Percentage of GDP

\begin{tabular}{llllll}
\hline & Eurozone & Spain & Ireland & Portugal & Greece \\
\hline 1998 & -2.03 & -1.736 & 1.219 & -3.4 & -2.86 \\
1999 & -1.6 & -1.02 & 0.269 & -3.38 & -1.89 \\
2000 & -1.969 & -1.22 & 1.673 & -4.7 & -2.68 \\
2001 & -2.676 & -1.757 & -1.8 & -5.5 & -3.647 \\
2002 & -2.86 & -1.1 & -2.757 & -4.9 & -4.1 \\
2003 & -3.1 & -0.976 & -3.167 & -4.89 & -6.03 \\
2004 & -2.98 & -0.978 & -2.75 & -5.2 & -8.638 \\
2005 & -2.67 & -1.598 & -3.756 & -5.7 & -6.01 \\
2006 & -2.07 & -1.275 & -4.0 & -3.9 & -4.9 \\
2007 & -1.83 & -1.132 & -7.3 & -3.4 & -6.795 \\
2008 & -2.58 & -4.9 & -11.26 & -4.02 & -11.47 \\
\hline $1998-2007$, & -2.38 & -1.28 & -2.24 & -4.5 & -4.76 \\
Mean (s.d.) & $(0.54)$ & $(0.31)$ & $(2.71)$ & $(0.09)$ & $(2.11)$ \\
\hline
\end{tabular}

SOURCES: EconStats and IMF World Economic Outlook. 
TABLE 2

Government Net Debt as a Percentage of GDP

\begin{tabular}{lcccc}
\hline & Spain & Ireland & Portugal & Greece \\
\hline 1998 & 57.37 & 53.22 & 42.96 & 71.73 \\
1999 & 54.48 & 47.8 & 42.01 & 75.85 \\
2000 & 50.27 & 36.67 & 41.97 & 77.41 \\
2001 & 47.54 & 27.3 & 46.39 & 81.15 \\
2002 & 44 & 25.13 & 48.12 & 84.47 \\
2003 & 41.3 & 22.7 & 51.22 & 81.93 \\
2004 & 38.58 & 19.94 & 53.28 & 82.88 \\
2005 & 34.71 & 15.92 & 57.95 & 84.07 \\
2006 & 30.53 & 12.16 & 58.77 & 81.66 \\
2007 & 26.52 & 12.18 & 58.1 & 80.35 \\
2008 & 30.36 & 23.04 & 61.13 & 83.4 \\
2009 & 43.73 & 36.41 & 72.08 & 96.83 \\
\hline $1998-2007$, & 42.53 & 27.3 & 50.08 & 80.25 \\
Mean (s.d.) & $(10.16)$ & $(14.53)$ & $(6.77)$ & $(4.14)$ \\
$2009 / 2007$ & 1.65 & 2.99 & 1.24 & 1.21 \\
$2007 / 1998$ & 0.53 & 0.43 & 1.42 & 1.16 \\
\hline
\end{tabular}

SourCES: EconStats and IMF World Economic Outlook.

government bailout of the private banking sector is seen in the row labeled 2009/2007, which indicates the government net debt ratio in the post-crisis year 2009 relative to its level in the pre-crisis year 2007. The difference relates both to the bailout and to the loss of tax revenues from the recession.

The government debt ratio, and hence debt burden (interest payments/GDP) was rising in Greece and Portugal from 1998 to 2007, before the crisis. The ratio of the debt burden in row 2007/1998 was 1.42 for Portugal, 1.16 for Greece, 0.53 for Spain, and 0.43 for Ireland.

One infers from these two tables that the origin of the crises in Greece and Portugal was the trend in government budgetary policy, where structural deficits led to debt burdens; whereas the origin of the crises in Ireland and Spain was primarily the private banking sector and subsequent government bailouts. The crucial questions addressed in this article are: What are the origins of these public and private debts? And what are "excessive" debts? 


\section{Role of the Private Sector in the Crises in Ireland and Spain}

In Ireland and Spain the structural budget deficits were lower than in the eurozone (Table 1). In these countries, the private sector (housing and banks) was the origin of the debt crisis. I first describe what happened in these countries, and then explain the economics underlying the bubble/crash, which leads into an analysis of early warning signals.

\section{Ireland}

The Celtic Tiger boom in the late 1980s brought sustained growth in employment, income, and household formation. ${ }^{1}$ Ireland's becoming a founding member of the eurozone brought a sustained fall in nominal interest rates, which in turn led to higher asset valuations. The growing construction boom was financed by Irish banks which in turn were financed by external financial markets where inexpensive funds were available. In the last four years of the boom from 2003 onward banks competed aggressively in the mortgage markets with little regard for the creditworthiness of the mortgagors. At the end of 2003, net indebtedness of Irish banks to the world was over 10 percent of GDP. By 2008 , borrowing mainly for property jumped to over 60 percent of GDP.

Even before the failure of Lehman Brothers in September 2008, Irish residential properties had been falling for more than 18 months. At no point throughout the period — even as the crisis neared—did the Central Bank of and the Financial Services Authority of Ireland staff believe that any of the institutions were facing serious underlying difficulties, let alone insolvency problems.

When the crisis occurred, the collapse of construction and the fall in property prices led to the insolvency of banks. Their net worth vanished. The state took large equity stakes in most banks and issued government guaranteed bonds. Although Ireland's public debt immediately prior to the crisis was low, the fiscal deficit and public sector borrowing surged (Table 2, row labeled 2009/2007). The primary reason for the surge in the deficit was the collapse of tax revenues in 2008-09 due to the collapse of the housing sector.

${ }^{1}$ This section draws on the Central Bank of Ireland (2010) report on "The Irish Banking Crisis.” 


\section{Spain}

Throughout the 1989-2006 period demand in the Spanish economy grew at 4.7 percent per annum, whereas output expanded by 3.8 percent per annum, driven by immigration and increased labor force participation. ${ }^{2}$ There was scarcely any growth in productivity. Since expenditures exceeded production, external debt grew and the real exchange rate-equal to the nominal rate times relative prices-appreciated. Insofar as the nominal exchange rate was fixed in the eurozone, Spanish prices and costs rose relative to the rest of the eurozone. The Spanish economy lost competitiveness.

Unlike previous expansions, the resort to financing was not chiefly by the public sector, which reduced its debt throughout the period (see Table 2). Instead it was the Spanish households and firms that swiftly increased their debts. The real estate market propelled the expansion. Housing prices climbed from an average rate of 1 percent per annum between 1995 and 1997 to 18 percent between 2003-04, or an annual average increase of 10 percent between 1995 and 2007.

What facilitated the growth in the debt was the availability of cheap credit in the international financial markets. As a result, the Spanish economy, which needed virtually no foreign funding in 1996, became a net borrower. In 2008 total net borrowing from the rest of the world was 9.1 percent of GDP.

When housing prices fell, the banks, which financed the housing sector, were unable to repay their loans to the international lenders. Governments responded forcefully to the intensification of the financial crisis. At first, measures had focused on the selective bailout of ailing systemic banks, supplementing the actions of central banks to prevent liquidity problems in the banking sector from becoming insolvency problems. However, the risks of financial collapse and the increasingly evident and heightened prospect of global recession led to the widespread approval of plans to support the financial sector and to boost aggregate demand via fiscal stimulus. The breadth of the measures adopted and the volume of resources mobilized were on an unprecedented scale. The effect of the crisis raised the government's relative net debt ratio to 1.65 for 2009/2007 from 0.53 for 2007/1998.

\footnotetext{
${ }^{2}$ This section draws on the Bank of Spain (2009) Annual Report 2008.
} 


\section{Cato Journal}

\section{Role of the Capital Market}

The low world rates of interest and high domestic growth led to a rise in housing prices. In the period 1991-2000, the growth rates in Ireland and Spain were very high and generated a boom in housing prices.

Table 3 indicates the large capital gains resulting from investment in housing in Ireland and Spain, relative to the eurozone. The mean capital gain was 13.2 percent in Ireland, 9.71 percent in Spain, and 5.16 percent in the eurozone. Irish and Spanish banks borrowed abroad at low rates of interest and loaned those funds to the housing industry. The anticipated return was the marginal product of capital plus the anticipated capital gain. Investors within and outside the eurozone ignored the default risk, and creditors in the eurozone did not have to consider an exchange rate risk.

Investors in the eurozone assumed that there was neither an exchange rate risk nor a default risk in holding assets denominated in the common currency. The capital market treated these countries

\section{TABLE 3}

Residential Property Prices in EU Countries (Annual Percentage Change: New and Existing Houses)

\begin{tabular}{lcrrrrrrr}
\hline & Germany & Ireland & Greece & Portugal & Spain & Italy & France & Eurozone \\
\hline 1996 & -1.1 & - & 9.9 & 1.7 & 1.4 & 2.4 & - & 2.0 \\
1997 & -1.9 & - & 8.2 & 3.6 & 2.8 & 3.4 & 0.1 & 2.3 \\
1998 & -1.6 & 22.6 & 14.4 & 4.5 & 5.8 & -1.4 & 1.9 & 2.5 \\
1999 & 1.4 & 22.5 & 8.9 & 9 & 7.7 & 0.8 & 7.1 & 4.9 \\
2000 & 0.2 & 20.5 & 10.6 & 7.7 & 8.6 & 3.9 & 8.8 & 6 \\
2001 & 0.2 & 14.0 & 14.4 & 5.4 & 9.9 & 6.0 & 1.9 & 5.5 \\
2002 & -1.9 & 6.1 & 13.9 & 0.6 & 15.7 & 12.6 & 8.3 & 6.8 \\
2003 & -1.2 & 14.3 & 5.4 & 1.1 & 17.6 & 7.2 & 11.7 & 6.4 \\
2004 & -1.4 & 11.5 & 2.3 & 0.6 & 17.4 & 7.0 & 15.2 & 7.2 \\
2005 & -1.5 & 7.2 & 10.9 & 2.3 & 13.4 & 8.6 & 15.3 & 7.6 \\
2006 & 0.3 & 13.4 & 12.2 & 2.1 & 10.4 & 5.8 & 12.1 & 6.4 \\
2007 & 0.3 & 0.9 & - & 1.3 & 5.8 & 5.0 & 6.1 & 4.3 \\
Mean & -0.68 & 13.3 & 10.1 & 3.3 & 9.71 & 5.11 & 8.05 & 5.16 \\
St.dev. & 1.1 & 7.23 & 3.8 & 2.8 & 5.43 & 3.7 & 5.27 & 1.97 \\
\hline
\end{tabular}

SourCE: BIS Housing Statistics, IFC Bulletin No. 31, annex 1. 
FIGURE 1

InTEREst Rate SpREAds versus the Bund

(BASIS POINTS)

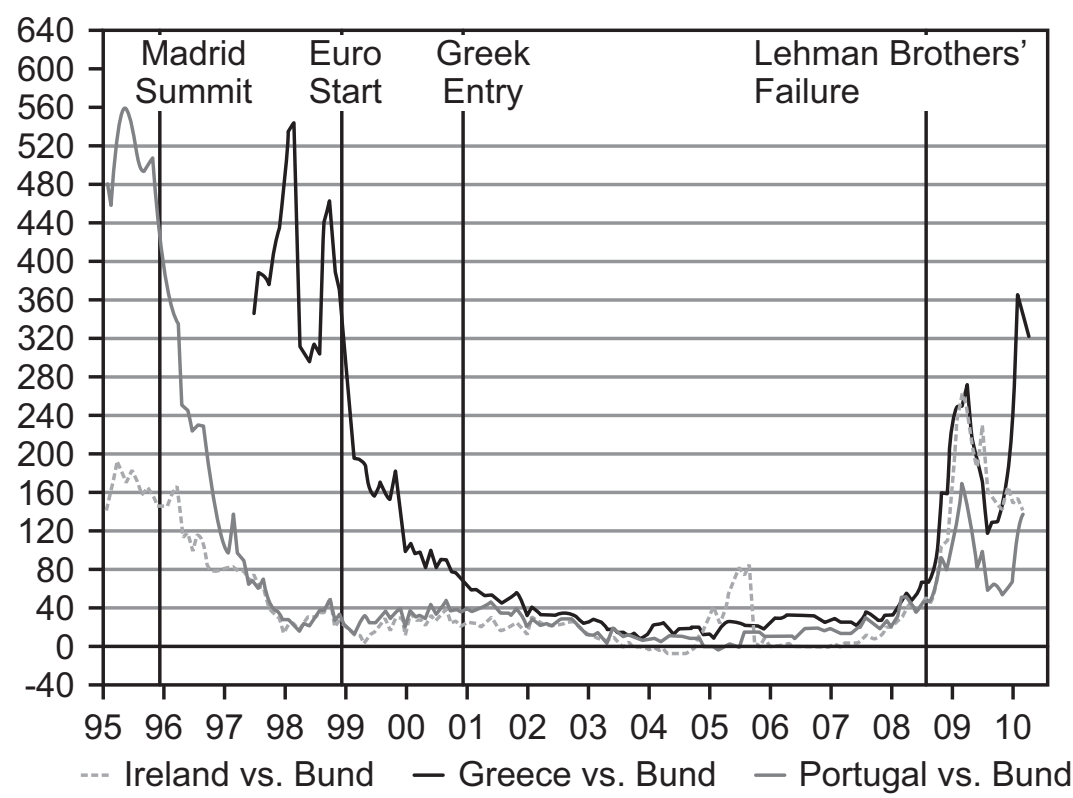

SourCE: Plagnol (2010), Reuters, Ecowin.

alike insofar as interest rates were concerned, and did not charge countries a risk premium relative to the rest of the eurozone during the period 2000-08. Figure 1 shows interest rate spreads for Ireland, Greece, and Portugal relative to the German Bund. From the time of the Greek entry in 2000 until 2008 when there was the Lehman Brothers failure, the spread was negligible. Hence, no debt problem was anticipated for these three countries. Effectively, there was a large supply of international funds at low interest rates to finance the gap between investment and social saving-resulting from the structural government budget deficit—in Greece and Portugal.

The credit default swap rate is the premium paid for insurance against default. ${ }^{3}$ The CDS rates for Ireland and Greece indicated little doubt about default until 2009. The rates for both were

${ }^{3}$ A CDS rate of y basis points means that it costs $\$ 1000 y$ to insure $\$ 10$ million of debt for five years. 


\section{Cato Journal}

below 100 basis points until the beginning of 2009. The CDS rate for Ireland ranged between 100 and 150 basis points, whereas for Greece the rate rose to 400 basis points.

The situation changed only when Lehman Brothers failed. Then the CDS rates and interest rates on Greek and Irish securities rose. The conclusion is that the market for bonds denominated in euros did not reflect doubts about default until quite late in the crisis. There were not early warning signals that were used by the markets. The precipitating factor in the recognition of default risk in Europe was the failure of Lehman Brothers. By then it was too late.

The ignoring of default risk stands in contrast with the U.S. experience where, despite having a common currency, the market evaluates municipalities according to the default risk. Neither the Treasury nor the Federal Reserve intervenes in the fiscal policies of the municipalities or contemplates bailouts when they are experiencing difficulties in servicing their debts. Table 4 presents the distribution of ratings, and hence interest rates that the capital market charges the various U.S. municipalities. Unlike Europe the discipline comes from the markets, not government.

\section{Evaluation of the Excessive Debt of the Private Sector}

Neither the markets nor the central banks anticipated the crises until it was too late. The basic question is: What is an "excessive" private sector debt ratio that is likely to lead to a crisis? The collapse of the housing market led to bank failures that led to bailouts. I now explain theoretically based, not empirical ad hoc, early warning signals of debt crises.

TABLE 4

U.S. Municipal Rating Distribution, 1970-2000

\begin{tabular}{lc}
\hline AAA & $3.15 \%$ \\
Aa & 11.50 \\
A & 54.42 \\
Baa & 29.90 \\
Ba & 0.80 \\
B & 0.13 \\
Caa-C & 0.02 \\
\hline
\end{tabular}

Source: Moody’s U.S. Municipal Bond Rating Scale, November 2002. 


\section{Leverage}

The crucial variable is leverage or the debt/net worth ratio, where

$$
\begin{aligned}
& \text { Leverage }=\text { assets/net worth }=1+\text { debt/net worth, } \\
& \text { and } \\
& \text { Net worth }=\text { assets }- \text { debt. }
\end{aligned}
$$

The growth of net worth is affected by leverage. An increase in debt to finance the purchase of assets increases the growth of net worth by the return on investment, but decreases the growth of net worth by the associated interest payments. The return on investment has two components: the productivity of assets and the capital gain on the assets. An increase in leverage will increase expected growth of net worth if the return on investment exceeds the interest rate. The productivity of assets is observed, but the future capital gain and the interest rates are unknown when the investment decision is made.

The basic equation for the growth of net worth is

$$
\begin{aligned}
& \text { Growth of net worth }=\text { debt ratio } \times(\text { capital gain }+ \\
& \text { return on assets }- \text { interest rate }) .
\end{aligned}
$$

This equation is crucial to understanding the excesses of the private sector and evaluation of desirable policy. A rise in the ratio of debt/net worth, say by banks, is used to purchase assets, say investments in housing. The increase in debt raises the growth of net worth if the anticipated capital gain on the assets, plus the rate of return on the assets, exceed the interest rate.

The capital gains are described in Table 3 and the interest rates in Figure 1. The huge capital gains in housing for Spain and Ireland, and low interest rates, during the period 2002-06, led to a rise in the debt ratio of the private sector. That is, the term in parentheses in equation 3 was large so the private housing sector increased its debt directly to banks and indirectly to foreign investors. The investment in housing seemed to be profitable because the debt could be refinanced or repaid from the recent capital gains, not from the marginal product of capital. But those capital gains (housing price appreciation in Table 3) were not sustainable.

The risk is that with the higher debt ratios, there would be a period when the capital gains fell below the interest rate, such as occurred in 2007 in Spain and Ireland. In fact the capital gain and interest rate terms are negatively correlated. When the growth of housing prices declined the banks tried to deleverage, and interest rates rose. The 


\section{Cato Journal}

term in parentheses became negative, and when multiplied by a large debt ratio the net worth of the housing industry vanished. Consequently, the housing sector defaulted on outstanding loans.

Bank failures followed the collapse of the housing market. The government then intervened to avert bank failures and purchased their bad debts in exchange for government debt. In Ireland and Spain, the debt crisis was due to the private sector and not to the government cyclically adjusted budget deficits.

\section{Early Warning Signals of an Excessive Private Debt}

The optimum debt ratio of the private sector, such as the housing sector, should maximize the expected logarithm of net worth at a terminal time. This strategy is risk averse because losses are more heavily weighted than are gains. The future capital gains and interest rates are unknown when the debt is incurred. This is a problem of stochastic optimal control (Stein 2006, 2010a, 2010b, 2011). It is reasonable to assume that capital gains consist of a trend or drift factor plus a stochastic (probabilistic) term, that the interest rate also has a trend or drift factor plus a stochastic (probabilistic) term, and that these two stochastic variables are negatively correlated.

On the basis of stochastic optimal control (SOC) analysis, the optimal ratio of debt/net worth has the following form:

$$
\begin{aligned}
& \text { Optimal debt/net worth }=(\text { drift capital gain }- \\
& \text { drift interest rate }+ \text { current return on assets }- \\
& \text { risk premium }) \times \text { risk factors. }
\end{aligned}
$$

The risk factors consist of variances of the capital gains, interest rates, and the correlation between those stochastic terms. It is not the current or recent capital gains and interest rates that are relevant but their trends or drifts over a longer period.

The SOC analysis implies that the expected growth of net worth is maximal when the optimal debt ratio is selected and that as the actual debt ratio rises above the optimum, the expected growth declines and the risk rises. Moreover, the excessive debt is an early warning signal of a crisis in the sector, such as housing or mortgages, where

$$
\begin{aligned}
& \text { Early warning signal }=\text { excess debt }=\text { actual }- \text { optimal } \\
& \text { debt ratio. }
\end{aligned}
$$

The housing sectors in Ireland and Spain selected debt ratios (leverage) based on capital gains during the period 2003-06. Those 
FIGURE 2

U.S. Household DebT vs. Return on Assets

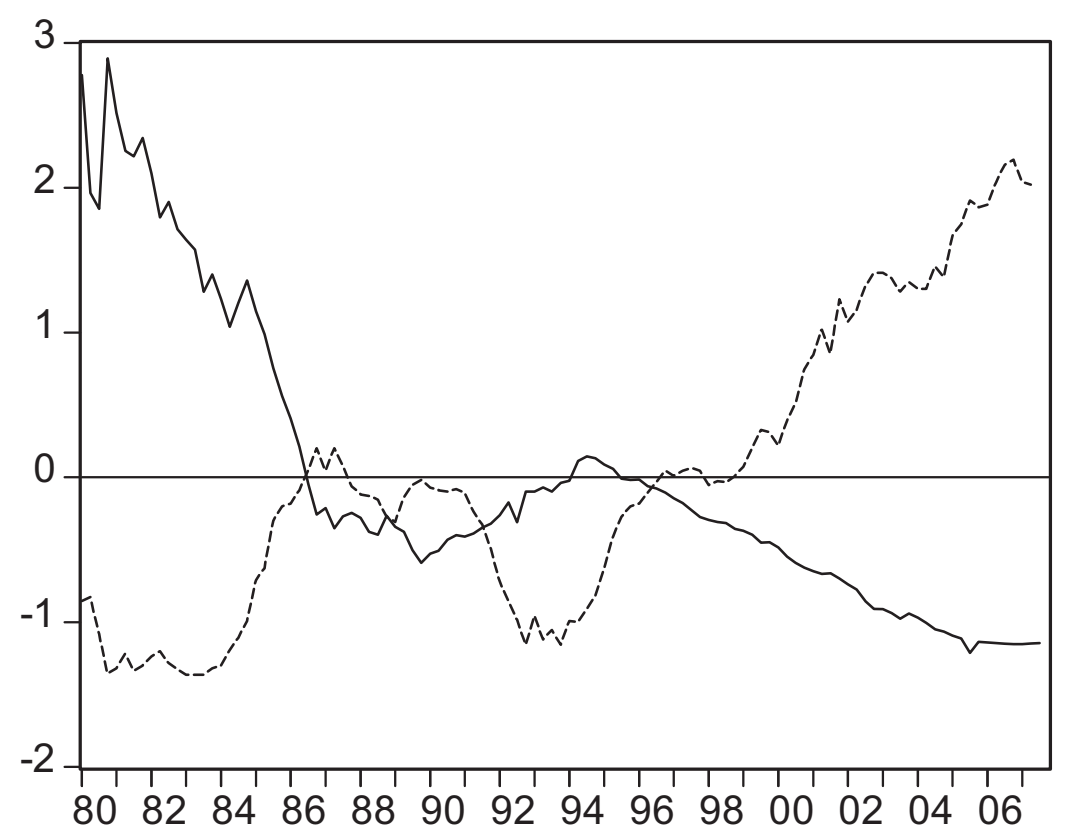

RENT PRICE ----- DEBT RATIO

rates far exceeded the interest rate and were unsustainable. The correct approach would have been to use the drifts of the capital gains and interest rates, adjusted for risk.

This type of early warning signal is clearly seen in the U.S. mortgage crisis. Figure 2 plots a unit-free (normalized) measure of the actual debt ratio (household debt/disposable income) and a unit-free measure of the optimal ratio of rental income to an index of housing prices. ${ }^{4}$ This "rent price" reflects the marginal product of capital. In the United States, the trend or drifts of the capital gains and interest rate were approximately equal.

An excessive debt of the households is seen in Figure 2 when the normalized debt ratio rises relative to the normalized value of the

${ }^{4}$ Normalized or unit-free variables are calculated as deviations from their longterm means divided by the standard deviation. For details on the calculations in Figure 2, see Stein (2010a, 2010b, 2011). 


\section{Cato Journal}

current return on assets (i.e., the rent price or marginal product of capital). From 2002 to 2006 , the return on assets declined more than one standard deviation below its long-term mean while the debt ratio rose two standard deviations above its long-term mean. This excessive debt ("debt ratio - rent price") signaled a situation where the debt can be serviced only from unsustainable capital gains.

The situations in Ireland and Spain during the period 2003-06, seen particularly in Table 3 , led to an excess debt because the housing sector and the banks assumed that the recent capital gains (far above their trends) were sustainable. These situations were similar to the S\&L crisis in the United States in the 1980s and the mortgage crisis of 2007-08. The excessive debt is an early warning signal of a crisis. In these countries the decline in net worth, and bankruptcy of the housing sector, led to the insolvency of the banking sector and to the bailout. The rise in government debt was simply an exchange of government debt for private debt.

\section{Fiscal Deficit and Public Debt}

Unlike Ireland and Spain, the debt crises in Greece and Portugal were due to the government sector. Tables 1 and 2 showed those differences. The Stability and Growth Pact rules had no value in predicting the Irish and Spanish crises, but clearly deficits and debt ratios are relevant in the cases of Greece and Portugal. It is instructive to consider specifically the case of Greece, though the Portuguese case was similar.

Greece's large fiscal deficit and huge public debt are the cumulative result of chronic macroeconomic imbalances, and are at the origin of the debt crisis. ${ }^{5}$ The global crisis simply aggravated Greece's fiscal performance and prospects, which had already begun to deteriorate in the second half of 2007 for reasons unassociated with the economic downturn. Indeed, the fiscal deficit has been above 3 percent of GDP almost every year for the past decade, thus exceeding the Maastricht criteria. According to revised data released by Eurostat on April 22, 2010, the deficit came to 5.1 percent in 2007, 7.7 percent in 2008, and 13.6 percent in 2009.

These adverse budgetary developments triggered the downgrading of Greece's credit rating and a sharp widening in the yield spread

\footnotetext{
${ }^{5}$ This section draws on annual reports from the Bank of Greece.
} 
of Greek government bonds vis-à-vis German bonds in late 2009 to mid-April 2010 (Figure 1). The high public debt at 115.1 percent of GDP in 2009 was the highest in the eurozone along with that of Italy, and is expected to keep rising at least through 2014.

According to Bank of Greece staff projections, the debt dynamics are unfavorable, as it is estimated that the fiscal adjustment envisaged will only lead to a stabilization of the debt-to-GDP ratio in 2014, at very high levels (over 130 percent), on the basis of conservative assumptions regarding nominal GDP growth over the next few years and the nominal interest rate on public debt. It is estimated that reducing the debt ratio to below 100 percent of GDP will require a systematic fiscal effort over a number of years, at a time when it is essential to restart the growth process and ensure that strong economic performance is restored within a reasonable time frame. The only option is to reform social security, implement the fiscal consolidation plan, and promote structural reforms to achieve economic growth.

\section{General Principle Evaluating the Government Debt Ratio}

The appropriate policies to prevent or remedy a debt crisis depend on the origin of the excessive debt. Members of the EU falsely assumed that adherence to the rules of the Stability and Growth Pact/Maastricht Treaty would prevent debt crises. Proposals for reform are still focused on these rules limiting government budget deficits and debt. The SGP rules, however, are arbitrary and not based upon economic analysis. They come from the following identity linking the growth rate of the economy, the budget deficit/GDP, and the debt/GDP:

$$
\text { Budget deficit/GDP }=\text { growth rate } \times \text { debt/GDP. }
$$

This identity will be satisfied if the debt ratio stabilizes relative to the budget deficit ratio at any arbitrary constant level. Given an arbitrary growth rate, this identity only determines the ratio budget deficit/debt. If the growth rate is 5 percent per annum and the deficit is constant at 3 percent, the debt ratio would be constant at 60 percent. If the deficit is constant at 6 percent, the debt ratio would be 120 percent. The EU and IMF still use the 60 percent debt ratio as a target for policy. These values have nothing to do with 


\section{Cato Journal}

whether the debt is optimal or "excessive" and are irrelevant as early warning signals of a crisis such as Europe has experienced.

It is not possible to establish an optimal debt ratio-and hence an excessive debt ratio-for the government, as it is for the private sector. However, the focus should be on the trend of debt burden, defined as interest payments on debt/GDP. Budget deficits should be viewed in terms of their effects on GDP. Will the borrowing (increase in debt) raise the productivity of the economy by more than the interest rate? If the marginal productivity exceeds the interest rate, the debt burden (interest payments/GDP) will decline. For example, in Central and Eastern European Countries lower tax rates could increase government debt but also lead to FDI that increases productivity. Similarly, the government may increase expenditures for education, health, and infrastructure, which raise productivity. Alternatively, government expenditures and tax reductions may simply stimulate consumption. For example, low-rent housing, subsidies, and minimum wage increases will not raise GDP. Since the interest payments exceed the marginal productivity of expenditure, the debt burden rises. Therefore, the focus should be upon the trend of government debt. The last row in Table 2 shows that government debt/GDP from 1998 to 2007 was 1.42 in Portugal and 1.16 in Greece; whereas in Spain it was 0.53 and in Ireland it was 0.43. It is clear that the origin of the debt crises in these two sets of countries clearly differs.

\section{Repercussions in Financial Markets}

It is difficult to separate bank debt from government debt when the governments have bailed out banks. The government (taxpayer) takes over the role of the debtor. There is reason to combine the two debtors. Table 5 displays the debts of the banks and governments (debtors are listed in rows and creditors in columns). Spain owed $\$ 220$ billion to the French and $\$ 238$ billion to the Germans. The major creditors were the French and German banks. The major creditors for Ireland were Britain and Germany. The last column is total debt to all countries in addition to those in the table.

When the crises occurred in Greece, Portugal, Ireland and Spain, whether due to the government or the private sector, defaults occurred or were threatened. If Spain defaulted, then assets of the British, French and German banks and governments declined in 
Debt Crises in Europe

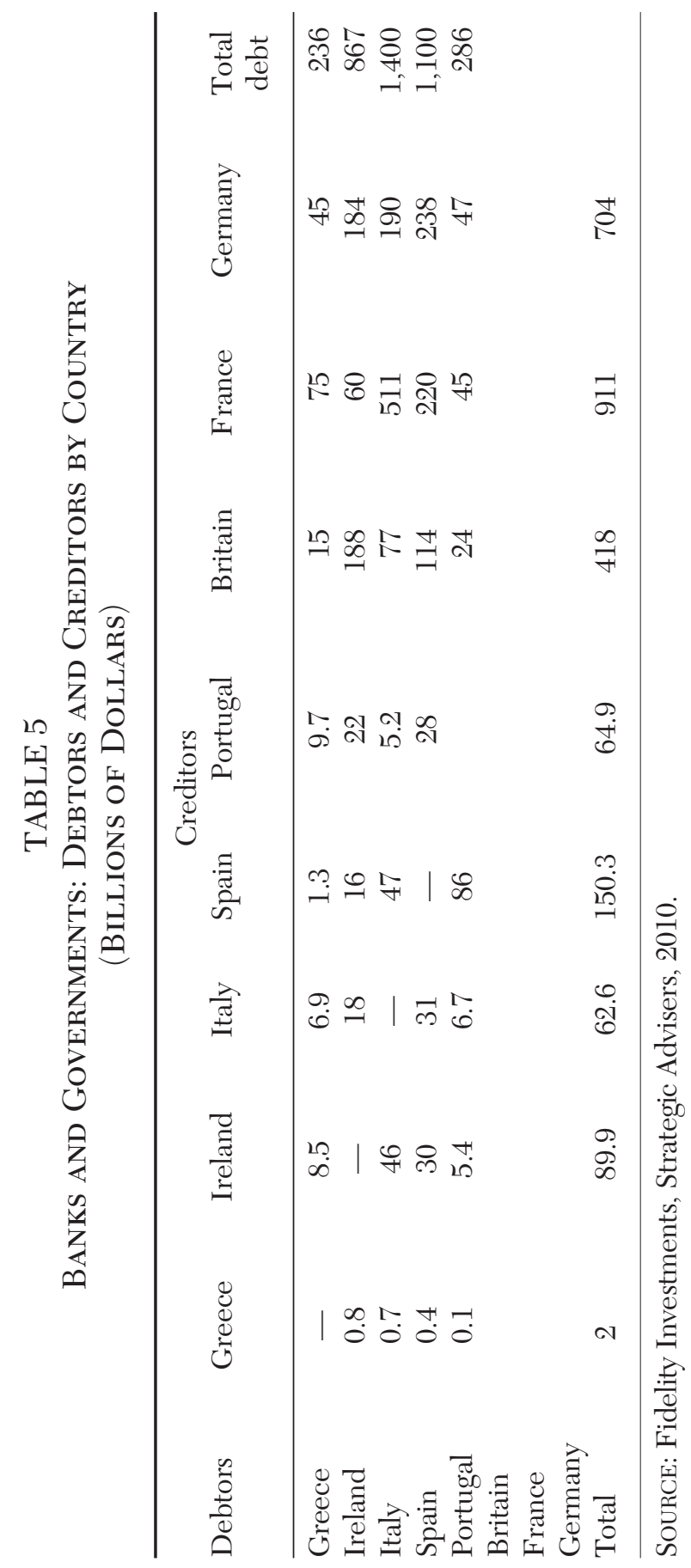




\section{Cato Journal}

value. If the Irish defaulted, the British and German banks and governments were affected.

\section{Conclusion}

The main causes of the debt crises in Europe varied by country. In Ireland and Spain, they were mainly due to the private sector, particularly housing. Those crises had great similarity to those in the United States - namely, the S\&L crisis, the agricultural crisis in the 1980s, and the mortgage crisis in 2007-08. In Greece and Portugal, the cyclically adjusted structural deficit was the major cause.

In Ireland and Spain, the domestic housing booms were financed from foreign borrowing. The creditors failed to require a risk premium related to the probability of default. The anticipated return was the sum of the marginal product of capital plus an anticipated capital gain or asset price appreciation. The marginal product of capital was below the rate of interest. The debt was anticipated to be refinanced from the capital gain in excess of the interest rate, not from current earnings. The anticipated capital gain was based on recent experience, which was unsustainable. The debts were excessive: the actual debt exceeded the optimal debt derived from stochastic optimal control analysis. When the capital gain fell below the rate of interest, the borrowers in the housing industry defaulted. Their creditors were the banks, which, in turn, were debtors to international lenders.

The optimal ratio of debt/net worth of the private sector is equal to the trend of the capital gain minus the trend of the interest rate plus the current return on assets minus a risk premium, all of that multiplied by risk factors consisting of variances of the capital gains, interest rates and the correlation between the stochastic terms. It is not the current or recent capital gains and interest rates that are relevant but their trends/drifts over a longer period. An early warning signal of a debt crisis is a significant excessive debtthe actual less the optimal debt ratio.

A sensible early warning signal for excessive government debt is the trend of the debt burden (interest payments/GDP). Insofar as the government deficits have a marginal product above the interest rate, the debt burden will tend to decline. Insofar as the budget deficits have marginal productivities below the interest rate, the 
debt burden will rise. In the cases of Greece and Portugal the trend was highly positive, wheras in Spain and Ireland the trend was negative.

\section{References}

Bank of Greece (various years) Annual Report. Athens.

Bank of Spain (2009) Annual Report 2008. Madrid: Banco de España. Available at www.bde.es.

Central Bank of Ireland (2010) "The Irish Banking Crisis: Regulatory and Financial Stability Policy, 2003-08." A Report to the Minister for Finance by the Governor of the Central Bank (31 May).

Eiglsperger, M., and Haine, W. (2009) "EU Housing Statistics." IFC Bulletin No. 31, Annex 1. Basel: Bank for International Settlements.

Plagnol, V. (2010) "European Bond Markets in Financial Crisis." Reuters, Ecowin.

Stein, J. L. (2006) Stochastic Optimal Control, International Finance, and Debt Crises. Oxford: Oxford University Press. (2010a) "Greenspan’s Retrospective of Financial Crisis and Stochastic Optimal Control." European Financial Management 16 (5): 858-71.

(2010b) "Greenspan, Dodd-Frank, and Stochastic Optimal Control.” CESifo Forum (April).

(2011) "The Crisis, Fed, Quants, and Stochastic Optimal Control." Economic Modelling 28: 272-80. 
